\title{
CHARACTERIZATION OF nAl POWDERS FOR ROCKET PROPULSION
}

\section{Merotto, L. Galfetti, G. Colombo, and L. T. DeLuca}

\author{
Politecnico di Milano \\ Aerospace Engineering Department \\ Via La Masa 34, Milan, Italy
}

\begin{abstract}
Nanosized metal powders are known to significantly improve both solid and hybrid rocket performance, but have some drawbacks in terms of cost, safety, and possible influence on propellant mechanical properties. Performance enhancement through nanosized metal or metal hydride addition to solid fuels is currently under investigation also for hybrid propulsion. Therefore, a preburning characterization of the powders used in solid propellant or fuel manufacturing is useful to assess their effects on the ballistic properties and engine performance. An investigation concerning the comparative characterization of several aluminum powders having different particle size, age, and coating is presented. Surface area, morphology, chemical species concentration and characteristics, surface passivation layers, surface and subsurface chemical composition, ignition temperature and ignition delay are investigated. The aim of this characterization is to experimentally assess the effect of the $\mathrm{nAl}$ powder properties on ballistic characteristics of solid fuels and solidrocket composite-propellant performance, showing an increase in terms of $I_{s}$ caused by the decrease of two-phase losses in solid and a possible significant $r_{f}$ increase in hybrid rockets.
\end{abstract}

\section{NOMENCLATURE}

$\begin{array}{ll}d & \text { particle diameter, } \mu \mathrm{m} \\ G & \text { total mass flux, } \mathrm{kg} /\left(\mathrm{m}^{2} \mathrm{~s}\right) \\ I_{s} & \text { specific impulse, } \mathrm{s} \\ r_{f} & \text { regression rate, } \mathrm{mm} / \mathrm{s} \\ S_{A} & \text { surface area, } \mathrm{m}^{2} / \mathrm{g} \\ t_{\text {ign }} & \text { ignition delay, } \mathrm{s}\end{array}$

This is an Open Access article distributed under the terms of the Creative Commons Attribution-Noncommercial License 3.0, which permits unrestricted use, distribution, and reproduction in any noncommercial medium, provided the original work is properly cited. 
$T_{\text {ign }}$ ignition temperature, ${ }^{\circ} \mathrm{C}$

$\theta \quad$ angle between the reticular plane and the incident radiation direction, rad

$\rho \quad$ aluminum density, $\mathrm{g} / \mathrm{cm}^{3}$

$\Phi \quad$ crystalline domain size, $\mathrm{nm}$

\section{Abbreviations}

$\begin{array}{ll}\mathrm{Al}_{\text {met }} & \text { metal aluminum } \\ \mathrm{Al}_{\text {ox }} & \text { aluminum oxide } \\ \mathrm{CCP} & \text { condensed combustion products } \\ \mathrm{EEW} & \text { electrical exploded wire } \\ \mathrm{MM} & \text { mechanical milling } \\ \mathrm{nAl} & \text { nanosized aluminum } \\ \mathrm{PC} & \text { plasma condensation } \\ \mathrm{SEM} & \text { scanning electron microscope } \\ \mathrm{XPS} & \text { X-ray photoelectron spectroscopy } \\ \mathrm{XRD} & \text { X-ray diffraction } \\ \mu \mathrm{Al} & \text { microsized aluminum }\end{array}$

\section{INTRODUCTION}

The behavior of $\mathrm{Al}$ and its oxides has been extensively investigated since the beginning of solid rocket history; combustion efficiency, burning rate, and twophase flow losses are peculiar aspects of the combustion process influenced by $\mathrm{Al}$ powders, discussed in milestone papers [1-3]. Great attention has been focused in recent years on formulations containing ultrafine energetic particles, particularly, Al nanoparticles [4-8], because of a series of advantages such as significant increases in propellant burning rates, shorter ignition delays, and shorter agglomerate burning times and agglomerate size. It is known that combustion of very small Al particles does not follow the classical diffusion model, suitable to describe coarse particle combustion (typical size above 15-45 $\mu \mathrm{m}$ ). For $\mathrm{nAl}$ particles, the limiting factor becomes the kinetics of the reaction rather than the transport. The burning rate becomes proportional to particle diameter $(d)$ and inversely proportional to pressure $(1 / p)$, while for microsized particles, it depends on the initial diameter squared $\left(d^{2}\right.$-law) and scarcely depends on ambient pressure. The transition regime (between the diffusion and kinetic limit) was extensively investigated in [9-11]. It was shown there that this regime is characterized by weakening of exponent $n$ in the $d^{n}$-law, an enhanced pressure dependence on the burning rate, and an enhanced initial temperature dependence. Nanoparticles can increase the burning rate of aluminized solid propellants by $100 \%$ or even more [12]. Problems connected with poor mechanical 
properties, a lower fraction of metal $\mathrm{Al}$ content compared to $\mu \mathrm{Al}$ powders, particles agglomeration, high reactivity with water and active binders, particle ageing (metal Al loss estimated at 1\%-2\% per year for storage in air [13]), and high cost limit the use of nanosized $\mathrm{Al}$ propellants and suggest further investigations.

In future, hybrid propulsion may become an important competitor for traditional chemical propulsion systems; performance enhancement through nanosized metal / metal hydride addition to solid fuels is currently under investigation [14-16]. Metal combustion mechanisms are known to play a major role in the performance of both solid rocket motors and hybrid engines, but such a role is expected not to be the same in the two cases, because of the different flame structure. Aluminum combustion time sensitivity with respect to particle diameter, pressure, and oxidizer was also investigated [17], but scarce data are available on metal combustion mechanisms in hybrid engine (diffusion flame) conditions.

Therefore, the characterization of powders used in solid propellant or fuel manufacturing is performed to assess their effects on the ballistic properties and motor performance. The purpose of this work is the characterization of several Al powders with different particle size and morphology, production technique, age, and particle coating. After a survey of characterization techniques and results, powders are compared in terms of ignition temperature and ignition delay. Results are then correlated with solid rocket propellant and solid fuel ballistic performance. Thus, this work allows relating the chemical and physical properties of metal powders to both solid fuel and solid rocket propellant performance, helping to select the most suitable $\mathrm{nAl}$. The advantage of $\mathrm{nAl}$ replacement in both solid and hybrid rockets is to decrease two-phase losses thus increasing $I_{s}$. A further advantage in solid rockets is the reduction of slug losses and, in hybrid rockets, is the increase of $r_{f}$.

\section{CHARACTERIZATION TECHNIQUES}

The surface area measurement, based on the kinetic model of the adsorptiondesorption process over a solid surface, developed by Brunauer, Emmett, and Teller (BET) [18], allows determining the surface area $\left(\mathrm{m}^{2} / \mathrm{g}\right)$ of a porous material or a powder; in this case, the surface area is inversely proportional to the particle size. The measurements of specific surface area are drawn out from nitrogen adsorption isotherms obtained by static volumetric measurements at liquid nitrogen boiling temperature $(77 \mathrm{~K})$. Samples have been outgassed at $100^{\circ} \mathrm{C}$ for $4 \mathrm{~h}$, at absolute pressure less than $10^{-3}$ Torr. All measurements have been carried out on a completely automated instrument (ASAP 2010-Micromeritics), leading to the final value of the specific surface areas expressed in $\mathrm{m}^{2} / \mathrm{g}$. 
Scanning electron microscopy (SEM) allows investigating the nanosized particle morphology. The microscope used in this work is a Cambridge Stereoscan 360 (maximum acceleration voltage $40 \mathrm{kV}$ ), equipped with $\mathrm{LaB}_{6}$ filament and a resolution of $3.5 \mathrm{~nm}$. Specimens are observed directly with no surface preparation.

X-ray photoelectron spectroscopy (XPS), based on electron photoemission, allows the surface chemical composition analysis of solid samples. X-ray photoelectron spectroscopy has been used, in addition to sputtering of $\mathrm{Ar}^{+}$ions at $4 \mathrm{keV}$, to obtain chemical depth profiles which give information on the surface passivation layers and allow chemical species to be quantified. The spectrometer is a PHI-mod.5500, with monochromatized Al source for X-ray production. The spectra have been taken at $300 \mathrm{~W}$. This analysis explores a volume with a relatively large surface area (hundreds microns) but a very thin thickness (about $10 \mathrm{~nm}$ ). In this work, sputtering was performed through the collision of $\mathrm{Ar}^{+}$ ions with a sample, causing erosion of the sample surface, therefore exposing the sample subsurface layers. The sputtering rate has been estimated around $6 \mathrm{~nm} / \mathrm{min}$, so that the time scale can be converted into a depth scale. It is worth noticing that, since the sputtering is applied to powder samples, the investigation leads to an average chemical composition on a certain number of particles. Therefore, it is not possible to relate directly the chemical profile obtained with the depth in the single $\mathrm{Al}$ particle, and the XPS results must be intended as an average on a thin powder film.

Powders X-ray diffraction (XRD) allows the analysis of the crystalline structure and the recognition of the crystalline phases in the sample. The comparison of the diffraction peaks angular positions with ad hoc databases (PDF-2, Powder Diffraction File, ICDD) allows identifying the crystalline compounds in the sample. A spectra postprocessing allows quantifying the species. A qualitative analysis of XRD spectra has been carried out by means of the standard powder method. In addition, a full profile fitting procedure, based on the Rietveld method $[19,20]$ allowed accurate quantitative analysis to be performed and complete structural refinements of each identified phase to be obtained. By means of the investigation of the intrinsic broadening of diffraction peaks, accurate values of coherent scattering-domain lengths have also been obtained.

The experimental setup used for the ignition temperature measurement was based on the use of a $\mathrm{CO}_{2}$ laser (wavelength $1.6 \mu \mathrm{m}$, power $80 \mathrm{~W}$ ) to heat a small amount of $\mathrm{Al}$ powder (about $1 \mathrm{mg}$ ) on the bottom part of a steel lamina. A thermocouple ( Pt-Pt Rh 10\%, $50 \mu \mathrm{m}$ bead), placed in the center of the powder heap put on the lamina upper side, and a photodiode allowed detecting ignition onset, temperature, and powder ignition time.

Propellant samples were prepared and tested at SPLab, according to wellestablished procedures [21, 22]. Propellant samples $(4.5 \times 4.5 \times 30 \mathrm{~mm})$ were burned in a nitrogen-flushed window bomb in order to measure the steady burning rate. The samples were ignited by a hot nichrome wire. The pressure was kept constant during the whole combustion process with a feedback pressure 


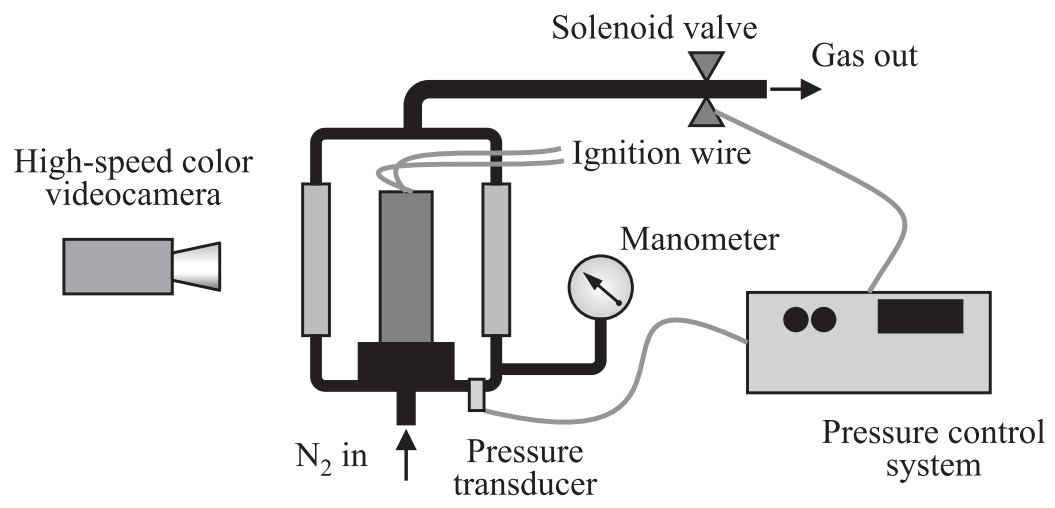

Figure 1 Experimental rig with windowed strand burner used for combustion tests

control system. Steady burning rates were measured in the range of 1-70 bar by an automated image processing technique from high-speed video recordings. Each experimental point was obtained by averaging over several (at least, three) samples, and several burning rate readings were taken for each sample.

A sketch of the test rig used is shown in Fig. 1.

A two-dimensional (2D) slab test facility was also designed and developed at SPLab to investigate the combustion processes and to characterize the behavior of metal powders added to hybrid solid fuels. The stand included a windowed, slab-geometry combustion chamber, an ignition system, and convenient devices for feeding, control, and extinction. Details about the experimental setup can be found in [23]. This device is based on a 2D slab chamber, useful to investigate the boundary layer and the flame structure, the metal powder behavior and the general development of the combustion process. A pressure transducer allows obtaining the combustion chamber pressure curve vs. time, from ignition to extinction. Grain ignition was obtained by a $\mathrm{Ni}-\mathrm{Cr}$ wire; the oxidizer flow rate was measured by a calibrated nozzle; a nitrogen feeding system allows for an immediate extinction in case of emergency. Tests were performed in order to obtain the average fuel regression rate $\left(r_{f}\right)$ vs. total mass flux $\left(G=G_{\text {ox }}+G_{\text {fuel }}\right)$ using the measured pressure trace.

\section{INVESTIGATED ALUMINUM PARTICLES}

Several Al powders were characterized in this work; they are summarized in Table 1. The first column reports the Al powder type and, when available, the ageing since manufacturing. The production technique is indicated in the second column: powders are produced via electrical exploded wire (EEW), mechanical 
Table 1 Investigated $\mathrm{Al}$ powders covering the range $0.04-50 \mu \mathrm{m}$

\begin{tabular}{|c|c|c|c|c|c|}
\hline $\begin{array}{cc}\mathrm{Al} & \mathrm{F} \\
\text { powder }\end{array}$ & $\begin{array}{l}\text { Production } \\
\text { technique }\end{array}$ & Source, type & $\begin{array}{c}\text { Diameter as } \\
\text { declared by } \\
\text { manufacturer, } \\
\mu \mathrm{m}\end{array}$ & $\begin{array}{l}\text { Surface } \\
\text { area, } \\
\mathrm{m}^{2} / \mathrm{g}\end{array}$ & $\begin{array}{c}\text { BET } \\
\text { average } \\
\text { diameter, } \\
\mu \mathrm{m}\end{array}$ \\
\hline Al_01a & EEW & Russia (SibTermoChim) Alex & 0.15 & $15.3 \pm 0.15$ & 0.15 \\
\hline $\mathrm{Al} \_01 \mathrm{~b}$ & EEW & Russia (SibTermoChim) Alex & 0.30 & $4.7 \pm 0.07$ & 0.47 \\
\hline $\mathrm{Al} \_01 \mathrm{c}$ & EEW & Russia (SibTermoChim) Alex & 0.10 & $16.4 \pm 0.06$ & 0.14 \\
\hline $\begin{array}{c}\mathrm{Al} \_02 \mathrm{a} \\
(1 \text { year old })\end{array}$ & EEW & $\begin{array}{c}\text { Russia (Institute ofHigh } \\
\text { Current Electronics, RAS) }\end{array}$ & 0.17 & $17.5 \pm 0.03$ & 0.13 \\
\hline $\begin{array}{c}\mathrm{Al} \_02 \mathrm{~b} \\
(2 \text { years old })\end{array}$ & EEW & $\begin{array}{c}\text { Russia (Institute ofHigh } \\
\text { Current Electronics, RAS) }\end{array}$ & 0.17 & $14.4 \pm 0.07$ & 0.15 \\
\hline $\begin{array}{c}\mathrm{Al}-02 \mathrm{c} \\
(5 \text { years old })\end{array}$ & EEW & $\begin{array}{l}\text { Russia (Institute of High } \\
\text { Current Electronics, RAS) }\end{array}$ & 0.17 & $12.6 \pm 0.1$ & 0.18 \\
\hline $\mathrm{Al} \_03 \mathrm{a}$ & MM & $\begin{array}{c}\text { Russia (Tomsk State } \\
\text { University) }\end{array}$ & 0.20 & $2.0 \pm 0.01$ & 1.11 \\
\hline $\mathrm{Al}-03 \mathrm{~b}$ & MM & $\begin{array}{c}\text { Russia (Tomsk State } \\
\text { University) }\end{array}$ & 0.40 & $1.5 \pm 0.01$ & 1.48 \\
\hline $\mathrm{Al}-03 \mathrm{c}$ & MM & $\begin{array}{c}\text { Russia (Tomsk State } \\
\text { University) } \\
\end{array}$ & 0.80 & $0.86 \pm 0.03$ & 2.58 \\
\hline $\mathrm{Al}-03 \mathrm{~d}$ & MM & $\begin{array}{c}\text { Russia (Tomsk State } \\
\text { University) }\end{array}$ & 2.50 & $0.73 \pm 0.01$ & 3.04 \\
\hline Al_-04a & $\mathrm{PC}$ & $\begin{array}{l}\text { Russia (Peter's Research } \\
\text { Center), coated }\end{array}$ & 0.20 & $6.1 \pm 0.06$ & 0.36 \\
\hline $\mathrm{Al}-04 \mathrm{~b}$ & $\mathrm{PC}$ & $\begin{array}{l}\text { Russia (Peter's Research } \\
\text { Center), coated }\end{array}$ & 0.28 & $6.7 \pm 0.02$ & 0.33 \\
\hline $\mathrm{Al} \_05$ & $\mathrm{PC}$ & U.K. (space industry supplier) & 30.00 & $0.1 \pm 0.01$ & 122.16 \\
\hline $\begin{array}{l}\mathrm{Al} \_06 \\
\text { flakes }\end{array}$ & MM & Italy (commercial supplier) & 50.00 & NAv & NAv \\
\hline $\mathrm{Al}_{-} 07$ & EEW & $\begin{array}{c}\text { Russia (SibTermoChim) } \\
\text { Alex-L, coated } \\
\end{array}$ & 0.10 & $13.7 \pm 0.06$ & 0.16 \\
\hline $\mathrm{Al}-08 \mathrm{~b}$ & EEW & $\begin{array}{c}\text { Source: Russia } \\
\text { (Institute of High Voltage } \\
\text { Research, TPU) }\end{array}$ & 0.10 & $12.8 \pm 0.1$ & 0.17 \\
\hline $\mathrm{Al} \_09 \mathrm{a}$ & $\mathrm{PC}$ & USA (AMCOM) & 0.09 & $23.6 \pm 0.04$ & 0.09 \\
\hline $\mathrm{Al} \_09 \mathrm{~b}$ & $\mathrm{PC}$ & USA (AMCOM) & 0.04 & $56.4 \pm 0.16$ & 0.04 \\
\hline
\end{tabular}

milling (MM), or plasma condensation (PC). Source, nominal diameter, surface area, and measured diameter are reported in other columns.

For the coarsest powder (Al_06 sample), surface area is not available because the value is below the experimental sensibility treshold. Powder Al_05 is used in space industry. Powder $\mathrm{Al}_{-} 06$ is a cheap powder selected to assess the feasibility of replacement. All other powders are attempts to replace standard with nanosized powders or finer microsized powders. The BET measured diameter, 
which is the one used for comparing the powders in this work, does not always correspond to the nominal one. Aluminum powders are stored in a glove box, under controlled conditions of temperature $\left(15-20^{\circ} \mathrm{C}\right)$ and humidity.

\section{CHARACTERIZATION RESULTS AND DISCUSSION}

\subsection{Specific Surface}

Specific surface was measured using the BET technique. Absorbed nitrogen volume is plotted as a function of relative pressure for two representative data sets. Figure 2 shows adsorbed gas curves for different particle-size powders.

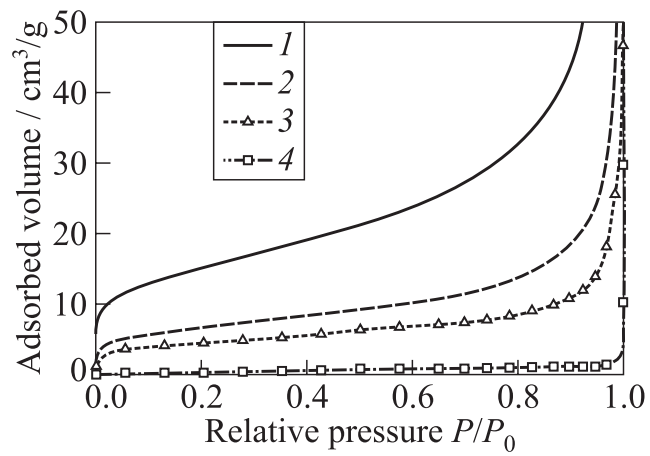

Figure 2 Adsorbed nitrogen volume vs. relative pressure for samples with different average diameter: $1-0.04 \mu \mathrm{m} ; 2-0.09 ; 3-0.14$; and $4-1.48 \mu \mathrm{m}$

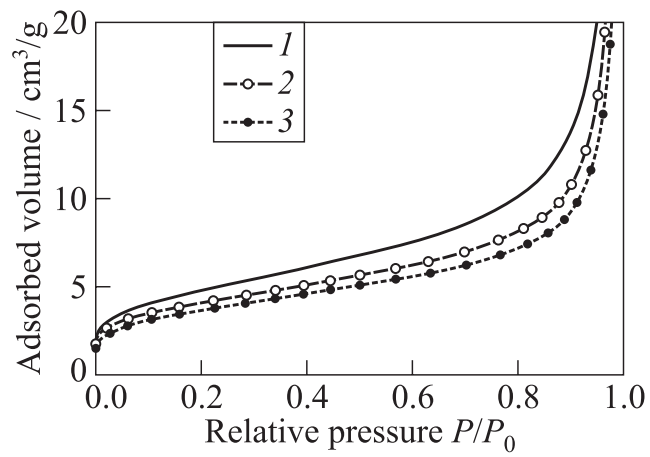

Figure 3 Adsorbed nitrogen volume vs. relative pressure for samples of different age: 1 - Al_02a, 1 year old; 2 - Al_02b, 2 years old; and 3 - Al_02c, 5 years old 
Figure 3 presents the same curves for powders of different age (Al_02a: 1 year old, Al_02b: 2 years old, Al_02c: 5 years old).

It can be observed that a higher adsorbed volume and higher curve slope are measured for finer particles (see Fig. 2), due to the higher surface area. Sample ageing results in lower curves (see Fig. 3). This trend suggests some change occurred with ageing; this aspect will be discussed in detail in the following subsections.

\subsection{Particle Morphology}

A micro- and a nanosized powders are compared in Figs. $4 a$ and $4 b$. Samples were analyzed as received.

In both cases, Al particles are spherical and display a bimodal size distribution. Nevertheless, in the microsized sample, particles show no cold cohesion, a phenomenon occurring at room temperature during storage, handling, and manufacture, which is responsible for microsized clusters reducing the specific surface. In the nanosized sample, groups of very fine particles cluster on the surface of a few coarse $(2-5 \mu \mathrm{m})$ particles. This behavior appears to be typical for nanosized powders. Micrographs of sample Al_06 are shown in Figs. $5 a$ (overall view) and $5 b$ (particle surface detail); irregular morphology and nonuniform size distribution can be observed for this sample.

Different aged samples micrographs are compared at the same magnification (younger sample in Fig. 6 and older sample in Fig. 7: ageing effect results in the presence of a gel covering older sample particles. Probably, air moisture is absorbed during sample storage, leading to a chemical change on the particle surface. This interpretation is confirmed by XPS analysis.

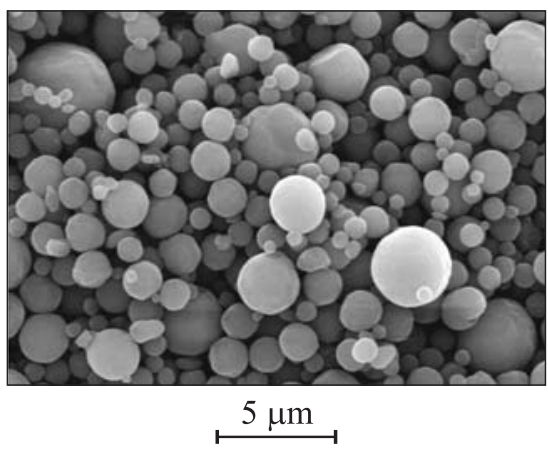

(a)

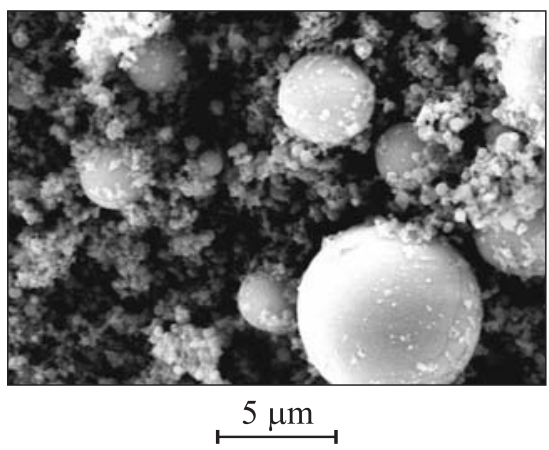

(b)

Figure 4 Samples Al_03a (a) and Al_04 (b). Magnification: 5000× 

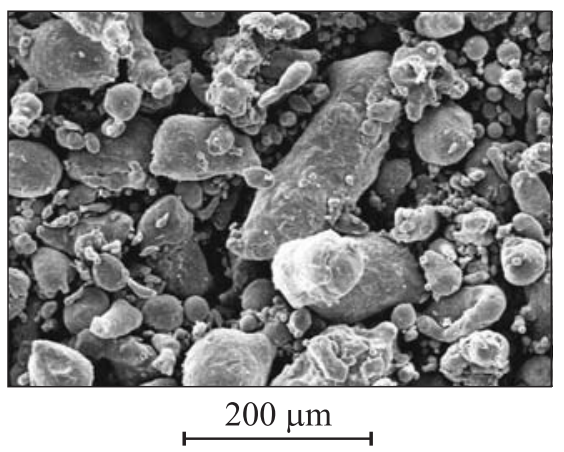

(a)

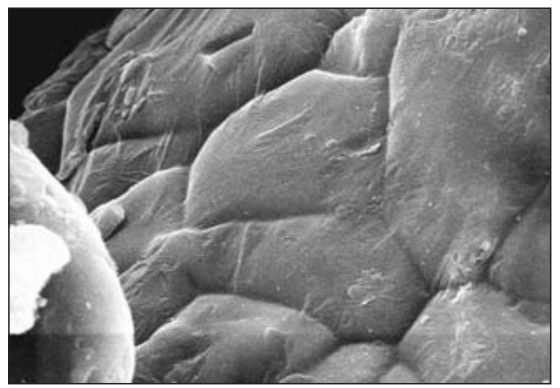

$5 \mu \mathrm{m}$

(b)

Figure 5 Samples Al_06. Magnification: $200 \times(a)$ and $5000 \times(b)$

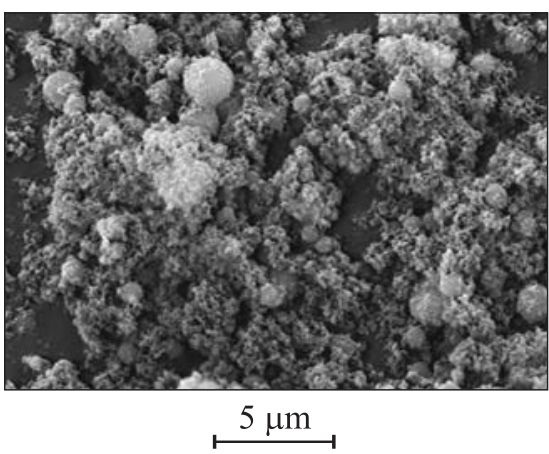

(a)

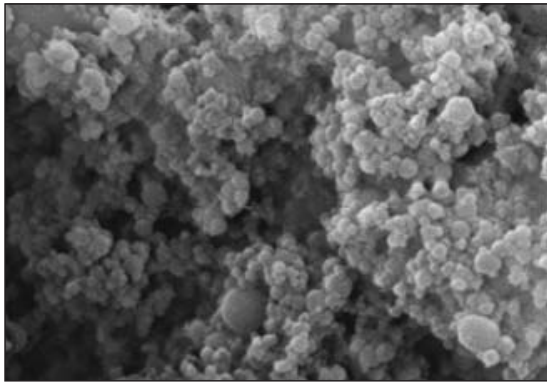

$0.5 \mu \mathrm{m}$

(b)

Figure 6 Sample Al_02a (1 year old). Magnification: 5000× $(a)$ and 50,000× $(b)$

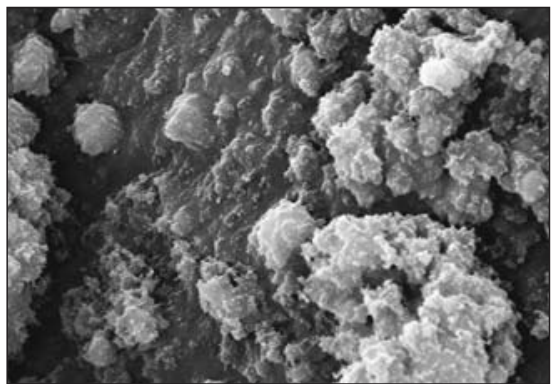

$5 \mu \mathrm{m}$

(a)

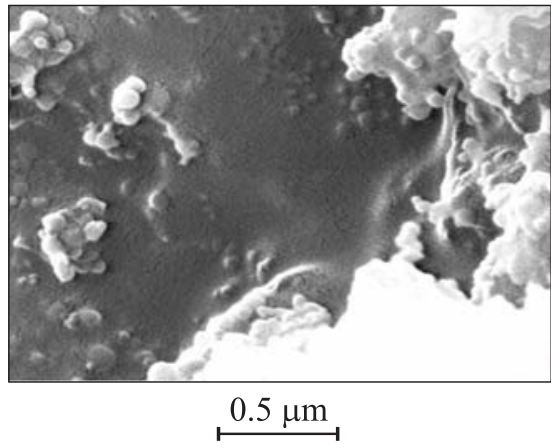

(b)

Figure 7 Sample Al_02c (5 years old). Magnification: $5000 \times(a)$ and 50,000× $(b)$ 
Aluminum particles are normally coated by a 2-4-nanometer layer of $\mathrm{Al}_{2} \mathrm{O}_{3}$. The low-temperature oxidation of $\mathrm{Al}$ particles occurs at least by 2 steps (see, for example, [24]). The first step builds a layer of a thickness between 6 and $10 \mathrm{~nm}$ composed of crystallites of the same size independent on the initial particle size. This reaction is dominated by chemical kinetics. The second step combines diffusion and chemical reaction and proceeds, therefore, slowly (the larger the particles, the slower the step).

Cliff and co-workers [25] investigated some $\mathrm{Al}$ powders in accelerated ageing conditions and showed that degraded $\mathrm{Al}$ powders produced bayerite $\left(\mathrm{Al}(\mathrm{OH})_{3}\right)$ as hydrolysis product rather than $\mathrm{Al}_{2} \mathrm{O}_{3}$. The results obtained in this work might thus indicate that an $\mathrm{Al}(\mathrm{OH})_{3}$ layer is formed on the aged $\mathrm{Al}$ powder surface. Nevertheless, further investigation is needed in order to determine if hydroxylation can occur at ambient conditions.

\subsection{X-Ray Photoelectron Spectroscopy Analysis}

Surface chemical analysis was performed using XPS technique, in order to obtain atomic concentration of chemical species along a thin layer immediately under the powder surface. Typical plots of atomic concentration vs. sputtering time are compared for microsized (Fig. 8a) and nanosized powders (Fig. 8b).
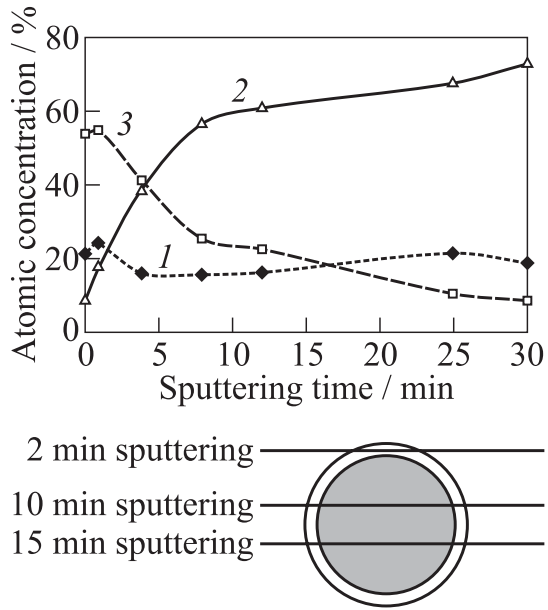

(a)

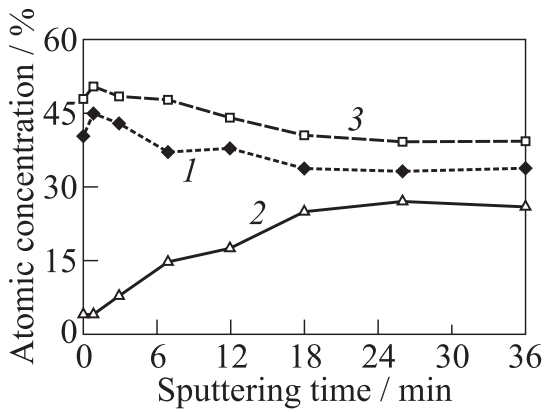

2 min sputtering

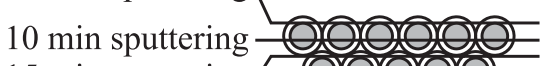
15 min sputtering $0(0)(0)$

(b)

Figure 8 Atomic concentrations of chemical species vs. sputtering time for sample Al_03d, measured average particle diameter $3.04 \mu \mathrm{m}(a)$ and Al_09b, measured average particle diameter $0.04 \mu \mathrm{m}(b): 1-\mathrm{Al}_{\mathrm{ox}} ; 2-\mathrm{Al}_{\mathrm{met}}$; and $3-\mathrm{O}$ 


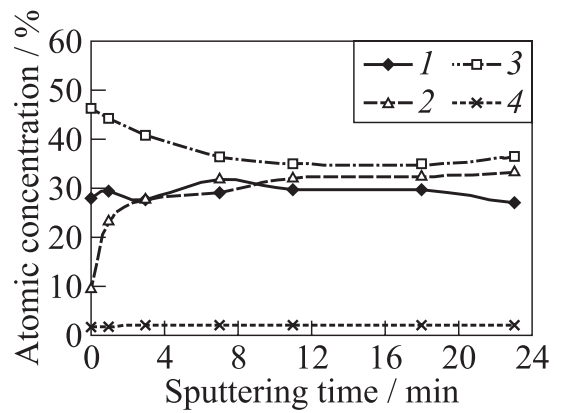

(a)

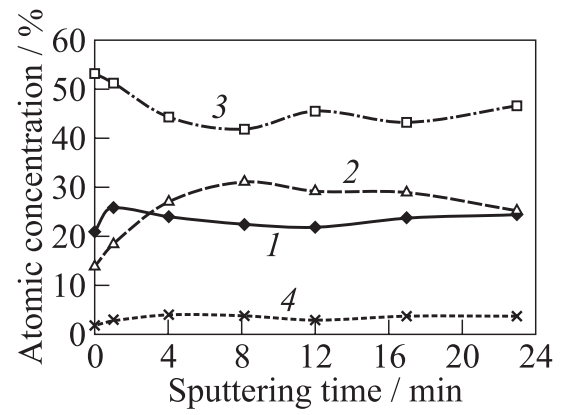

(b)

Figure 9 Atomic concentrations of chemical species vs. sputtering time for samples Al_02a $(a)$ and Al_02c $(b): 1-\mathrm{Al}_{\mathrm{ox}} ; 2-\mathrm{Al}_{\mathrm{met}} ; 3-\mathrm{O}$; and $4-\mathrm{N}$

The metal $\mathrm{Al}$ content $\left(\mathrm{Al}_{\text {met }}\right)$ vs. oxide $\mathrm{Al}$ content $\left(\mathrm{Al}_{\mathrm{ox}}\right)$ ratio appears to be directly related to particle size: a higher $\mathrm{Al}_{\text {met }} / \mathrm{Al}_{\text {ox }}$ ratio is typical of a coarser particle. Furthermore, for nanosized powders (see Fig. 8b) Al atomic concentration is lower than $\mathrm{Al}$ oxide concentration, while for microsized powders, $\mathrm{Al}_{\text {met }}$ is higher than $\mathrm{Al}_{\text {ox }}$. Moreover, a plateau is reached in $\mathrm{Al}_{\text {met }}$ for nanosized powders when particle core is under erosion. This is due to the erosion of different nanoparticle layers in the sputtering time considered. This phenomenon is illustrated in Fig. 8 (bottom), in which the comparison of the sputtering effect for micro- and nanosized particles is shown. After a sputtering time of $2 \mathrm{~min}$, the oxide coating layers are being eroded in both cases; correspondingly, a high $\mathrm{Al}_{\mathrm{ox}}$ content and a low $\mathrm{Al}_{\text {met }}$ content is measured. As sputtering goes on (10 min), the particle core is eroded, leading to high $\mathrm{Al}_{\text {met }}$ measurement. At 15-minute sputtering, in coarser particles, measurement erosion is still in a particle core, while in nanoparticles, a new particle layer (and, thus, a new oxide coating) is being eroded. Since the oxide layer thickness is similar in both cases when coarser particles are considered, the $\mathrm{Al}_{\text {met }}$ content percentage is higher than for finer particles. This explains the different trend in the concentration curves.

Concentrations of chemical species vs. sputtering time for differently aged samples are plotted in Fig. 9. Here, the samples having the same particle size, the same production method, coming from the same supplier are compared. The older sample displays a higher oxygen atomic concentration (45\%) than the younger one (35\%), thus suggesting that a different chemical species is covering the sample surface. The atomic concentrations of chemical species measured after 12-minute sputtering for all the investigated powders are listed in Table 2. The $\mathrm{O} / \mathrm{Al}_{\mathrm{ox}}$ ratio column gives information on the type of oxide formed: a stoichiometry of about 1.5 corresponds to alumina, while a value of 2.1 (powder $\mathrm{Al} \_02 \mathrm{c}$ ) is compatible with $\mathrm{Al}$ hydroxide. Thus, the chemical analysis confirms 
Table 2 Atomic concentrations of chemical species measured after 12-minute sputtering; $\mathrm{O} / \mathrm{Al}_{\mathrm{ox}}$ ratio gives an indication of the surface layer type; $\mathrm{Al}_{\text {met }} / \mathrm{Al}_{\mathrm{ox}}$ ratio is proportional to the particle average size

\begin{tabular}{|c|c|c|c|c|c|c|c|c|c|}
\hline Al type & $\mathrm{O}$ & $\mathrm{Al}_{\mathrm{ox}}$ & $\mathrm{Al}_{\text {met }}$ & $\mathrm{N}$ & $\mathrm{C}$ & Boron & $\mathrm{O} / \mathrm{Al}_{\mathrm{ox}}$ & $\mathrm{Al}_{\text {met }} / \mathrm{Al}_{\text {ox }}$ & $\mathrm{Al}_{\text {tot }}$ \\
\hline Al_01a & 33 & 24 & 39 & 1.5 & - & - & 1.4 & 1.6 & 63 \\
\hline Al_01b & 23 & 23 & 52 & - & - & - & 1.0 & 2.3 & 75 \\
\hline $\mathrm{Al} \_01 \mathrm{c}$ & 27 & 25 & 47 & 0.7 & - & - & 1.1 & 1.9 & 72 \\
\hline Al_02a & 35 & 30 & 32 & 2.0 & - & - & 1.2 & 1.1 & 62 \\
\hline Al_02b & 35 & 28 & 33 & 2.0 & - & - & 1.3 & 1.2 & 61 \\
\hline $\mathrm{Al} \_02 \mathrm{c}$ & 46 & 22 & 29 & 3.0 & - & - & 2.1 & 1.3 & 51 \\
\hline Al_03a & 15 & 17 & 68 & - & - & - & 0.9 & 4.0 & 85 \\
\hline Al_03b & 7.6 & 13 & 79 & - & - & - & 0.6 & 6.1 & 92 \\
\hline $\mathrm{Al} \_03 \mathrm{c}$ & 9 & 14 & 77 & - & - & - & 0.6 & 5.5 & 91 \\
\hline Al_03d & 22 & 16 & 60 & - & - & - & 1.4 & 3.8 & 76 \\
\hline Al_04a & 19 & 16 & 63 & 1.0 & 1.3 & - & 1.2 & 3.9 & 79 \\
\hline $\mathrm{Al}-04 \mathrm{~b}$ & 17 & 17 & 64 & 1.2 & 0.8 & - & 1.0 & 3.8 & 81 \\
\hline $\mathrm{Al}_{-} 05$ & 12 & 15 & 72 & - & - & - & 0.8 & 4.8 & 87 \\
\hline $\mathrm{Al} \_06$ & 8 & 6 & 86 & - & - & - & 1.3 & 14.3 & 92 \\
\hline $\mathrm{Al} \_07$ & 17 & 18 & 54 & 1.0 & 10.0 & - & 0.9 & 3.0 & 72 \\
\hline $\mathrm{Al}_{-} 08$ & 28 & 21 & 49 & - & 1.0 & 0.3 & 1.3 & 2.3 & 70 \\
\hline Al_09a & 35 & 30 & 34 & - & - & - & 1.2 & 1.2 & 64 \\
\hline Al_09b & 44 & 38 & 18 & - & 0.6 & - & 1.2 & 0.5 & 56 \\
\hline
\end{tabular}

the assumption that there has been a change in the chemical composition layer covering the older sample surface.

Chemical analysis revealed a particle coating different from $\mathrm{Al}$ oxide. Examples are shown in Fig. 10. In the first case, an organic coating (palmitic acid)

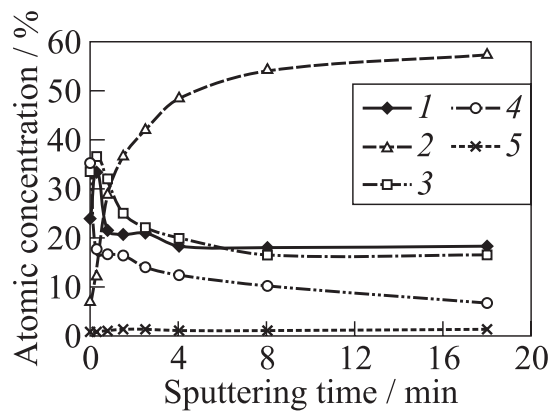

(a)

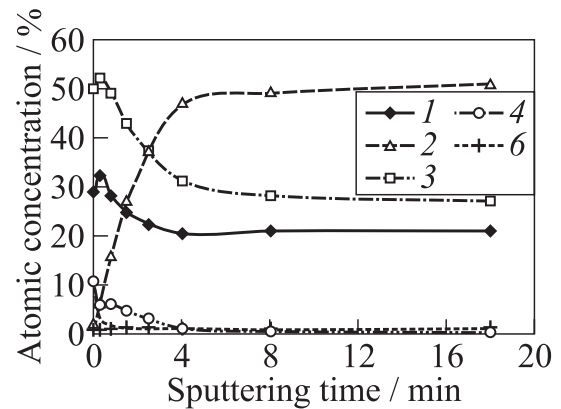

(b)

Figure 10 Atomic concentrations of chemical species vs. sputtering time for samples $\mathrm{Al}_{-} 07$ ( $a$ and $\mathrm{Al}_{-} 08(b): 1-\mathrm{Al}_{\mathrm{ox}} ; 2-\mathrm{Al}_{\mathrm{met}} ; 3-\mathrm{O} ; 4-\mathrm{C} ; 5-\mathrm{N}$; and $6-\mathrm{B}$ 
covers the particles; the XPS analysis measured a 15 percent concentration of carbon on the surface, and a small amount of nitrogen. In the second case, boron was detected among the species, together with a small amount of carbon.

\subsection{X-Ray Diffraction Analysis}

Figure 11 shows a nanosized sample XRD spectrum. For this powder (Al_09b, 0.04-micrometer BET average diameter), only $\mathrm{Al}$ peaks are detected, indicating no other crystalline phase in the sample. Figure 12 shows the XRD spectrum for Al_07 powder; Al nitride (AlN) phase is detected. Since no other crystalline phase is detected through XRD analysis, the carbon-based coating resulting from XPS analysis must be amorphous. This is consistent with the indication that the

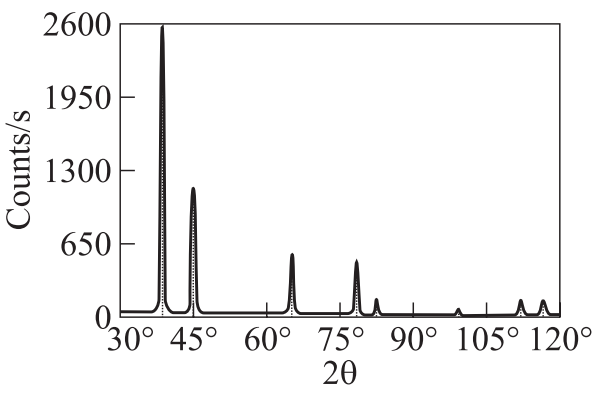

Figure 11 The XRD spectrum of nanosized sample Al_09b; the only phase detected is $\mathrm{Al}$ coating is palmitic acid.

The XRD results concerning the crystalline phases and their relative amounts are presented in Table 3. All powders prepared by the EEW (Electrical Explosion of Wires) technique contain two crystalline phases: the larger fraction is $\mathrm{Al}_{\text {met }}$ (more than 90\%), but a smaller fraction (less than 10\%) of AlN is also detected. Powders obtained by other techniques only contain $\mathrm{Al}_{\text {met }}$ as a crystalline phase.

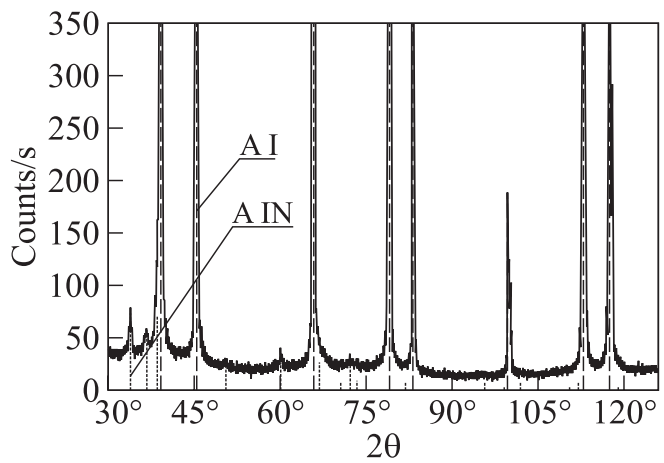

Figure 12 The XRD spectrum of an organic-coated aluminum powder (Al_07); Al and AlN phases are detected 
Table 3 The XRD results, showing the presence of AlN detected for powders obtained with EEW technique. The lattice-domain average size is also indicated

\begin{tabular}{|c|c|c|c|}
\hline \multirow{2}{*}{\multicolumn{2}{|c|}{ Aluminum type }} & \multicolumn{2}{|c|}{ Identified phases } \\
\hline & & $\mathrm{Al}$ & AlN \\
\hline \multirow{2}{*}{ Al_01a } & $\%$ & 96.5 & 3.5 \\
\hline & $\Phi, \mathrm{nm}$ & $150 \pm 20$ & $20 \pm 5$ \\
\hline \multirow{2}{*}{ Al_01b } & $\%$ & 100 & - \\
\hline & $\Phi, \mathrm{nm}$ & $330 \pm 10$ & - \\
\hline \multirow{2}{*}{$\mathrm{Al}_{-} 01 \mathrm{c}$} & $\%$ & 98.2 & 1.8 \\
\hline & $\Phi, \mathrm{nm}$ & $140 \pm 10$ & $20 \pm 5$ \\
\hline \multirow{2}{*}{$\mathrm{Al}-02 \mathrm{a}$} & $\%$ & 95.5 & 4.5 \\
\hline & $\Phi, \mathrm{nm}$ & $160 \pm 10$ & $35 \pm 5$ \\
\hline \multirow{2}{*}{$\mathrm{Al}-02 \mathrm{~b}$} & $\%$ & 94.1 & 5.9 \\
\hline & $\Phi, \mathrm{nm}$ & $150 \pm 10$ & $32 \pm 5$ \\
\hline \multirow{2}{*}{$\mathrm{Al} \_02 \mathrm{c}$} & $\%$ & 92.2 & 7.8 \\
\hline & $\Phi, \mathrm{nm}$ & $150 \pm 10$ & $34 \pm 5$ \\
\hline \multirow{2}{*}{ Al_03a } & $\%$ & 100 & - \\
\hline & $\Phi, \mathrm{nm}$ & $\infty$ & - \\
\hline \multirow{2}{*}{ Al_03b } & $\%$ & 100 & - \\
\hline & $\Phi, \mathrm{nm}$ & $\infty$ & - \\
\hline \multirow{2}{*}{$\mathrm{Al}_{-} 03 \mathrm{c}$} & $\%$ & 100 & - \\
\hline & $\Phi, \mathrm{nm}$ & $\infty$ & - \\
\hline \multirow{2}{*}{ Al_03d } & $\%$ & 100 & - \\
\hline & $\Phi, \mathrm{nm}$ & $\infty$ & - \\
\hline \multirow{2}{*}{$\mathrm{Al}-04 \mathrm{a}$} & $\%$ & 98.7 & 1.3 \\
\hline & $\Phi, \mathrm{nm}$ & $280 \pm 30$ & $26 \pm 5$ \\
\hline \multirow{2}{*}{$\mathrm{Al} \_04 \mathrm{~b}$} & $\%$ & 81.2 & 18.8 \\
\hline & $\Phi, \mathrm{nm}$ & 340 & n.a. \\
\hline \multirow{2}{*}{$\mathrm{Al}_{-} 05$} & $\%$ & 100 & - \\
\hline & $\Phi, \mathrm{nm}$ & $400 \pm 100$ & - \\
\hline \multirow{2}{*}{$\mathrm{Al}{ }_{-} 06$} & $\%$ & 100 & - \\
\hline & $\Phi, \mathrm{nm}$ & $\infty$ & - \\
\hline \multirow{2}{*}{$\mathrm{Al}_{-} 07$} & $\%$ & 97.5 & 2.5 \\
\hline & $\Phi, \mathrm{nm}$ & $140 \pm 30$ & $23 \pm 5$ \\
\hline \multirow{2}{*}{$\mathrm{Al}_{-} 08$} & $\%$ & 100 & - \\
\hline & $\Phi, \mathrm{nm}$ & n.a. & - \\
\hline \multirow{2}{*}{ Al_09a } & $\%$ & 100 & - \\
\hline & $\Phi, \mathrm{nm}$ & 128 & - \\
\hline \multirow{2}{*}{$\mathrm{Al}-09 \mathrm{~b}$} & $\%$ & 100 & - \\
\hline & $\Phi, \mathrm{nm}$ & 60 & - \\
\hline
\end{tabular}


The crystalline domain size $(\Phi)$ represents the maximum extension of regions with an ordered crystalline structure. This length is generally smaller than the particle size, because amorphous material can embed the crystals. The samples of the Al_ 03 series show an infinite length of crystalline domains, which means that they are larger than $1 \mu \mathrm{m}$.

\subsection{Ignition Temperature and Ignition Delay}

Ignition temperature $\left(T_{\text {ign }}\right)$ and ignition delay $\left(t_{\text {ign }}\right)$ were measured for all tested samples. Results are reported in Table 4, together with the surface area and measured average particle diameter. The results on $T_{\text {ign }}$ and $t_{\text {ign }}$ are plotted vs. surface area in Figs. $13 a$ and 13b, respectively. The presented values were obtained as the standard deviation value over the ignition tests performed for each powder.

Both, ignition temperature and ignition delay, are lower for a finer particle size. In particular, comparing the finest $(0.04 \mu \mathrm{m})$ and the coarsest $(3.04 \mu \mathrm{m})$

Table 4 Ignition temperature and ignition delay measured with laser heated plate for all tested samples. Results are correlated to the measured average particle diameter, confirming the correlation between average particle diameter and both ignition temperature and ignition delay

\begin{tabular}{|c|c|c|c|c|}
\hline Al type & $\begin{array}{c}\text { Ignition } \\
\text { temperature } \\
T_{\text {ign }},{ }^{\circ} \mathrm{C} \\
\end{array}$ & $\begin{array}{c}\text { Ignition delay } \\
t_{\text {ign }}, \mathrm{s}\end{array}$ & $\begin{array}{c}\text { BET surface } \\
\text { area, } \\
\mathrm{m}^{2} / \mathrm{g} \\
\end{array}$ & $\begin{array}{c}\text { BET measured } \\
\text { average diameter, } \\
\mu \mathrm{m}\end{array}$ \\
\hline $\mathrm{Al} \_09 \mathrm{~b}$ & $526 \pm 10$ & $0.87 \pm 0.13$ & 56.4 & 0.04 \\
\hline Al_09a & $571 \pm 7$ & $0.93 \pm 0.12$ & 23.6 & 0.09 \\
\hline $\mathrm{Al}-02 \mathrm{a}$ & $610 \pm 12$ & $0.91 \pm 0.07$ & 17.5 & 0.13 \\
\hline $\mathrm{Al}-01 \mathrm{c}$ & $676 \pm 17$ & $1.06 \pm 0.07$ & 16.4 & 0.14 \\
\hline Al_01a & $659 \pm 7$ & $1.15 \pm 0.50$ & 15.3 & 0.15 \\
\hline $\mathrm{Al}-02 \mathrm{~b}$ & $616 \pm 17$ & $1.45 \pm 0.08$ & 14.4 & 0.15 \\
\hline $\mathrm{Al} \_07$ & $647 \pm 12$ & $1.10 \pm 0.04$ & 13.7 & 0.16 \\
\hline Al_08b & $696 \pm 12$ & $1.22 \pm 0.06$ & 12.8 & 0.17 \\
\hline $\mathrm{Al}-02 \mathrm{c}$ & $604 \pm 17$ & $1.30 \pm 0.09$ & 12.6 & 0.18 \\
\hline $\mathrm{Al} \_04 \mathrm{~b}$ & $729 \pm 5$ & $1.48 \pm 0.06$ & 6.7 & 0.33 \\
\hline $\mathrm{Al}-04 \mathrm{a}$ & $711 \pm 20$ & $1.49 \pm 0.12$ & 6.1 & 0.36 \\
\hline Al_o1b & $613 \pm 7$ & $1.26 \pm 0.13$ & 4.7 & 0.47 \\
\hline $\mathrm{Al} \_03 \mathrm{a}$ & $742 \pm 10$ & $1.20 \pm 0.20$ & 2.0 & 1.11 \\
\hline Al_03b & $950 \pm 5$ & $3.00 \pm 0.01$ & 1.5 & 1.48 \\
\hline $\mathrm{Al} \_03 \mathrm{c}$ & $947 \pm 5$ & $2.10 \pm 0.01$ & 0.9 & 2.58 \\
\hline $\mathrm{Al} \_03 \mathrm{~d}$ & $1020 \pm 40$ & $2.00 \pm 0.20$ & 0.7 & 3.04 \\
\hline $\mathrm{Al} \_05$ & n.a. & n.a. & 0.1 & 22.16 \\
\hline $\mathrm{Al}_{-} 06$ & n.a. & n.a. & n.a. & n.a. \\
\hline
\end{tabular}




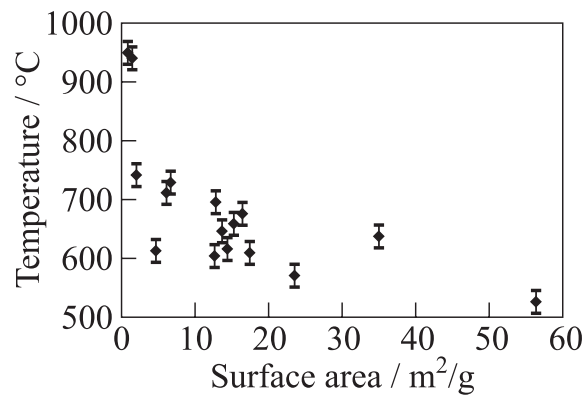

(a)

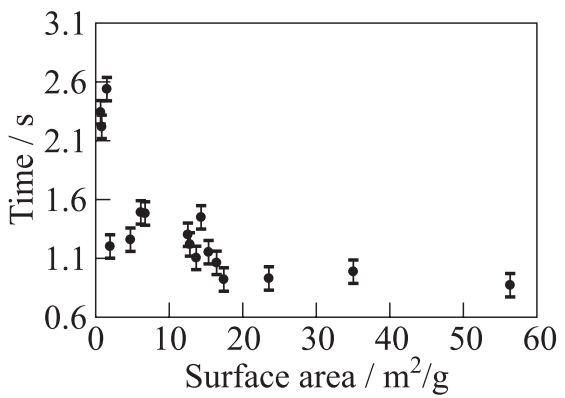

(b)

Figure 13 Ignition temperature $(a)$ and ignition delay after laser onset $(b)$ vs. surface area for different $\mathrm{Al}$ powders tested

particles investigated, the ignition temperature almost doubles $\left(526\right.$ and $1020^{\circ} \mathrm{C}$, respectively). Correspondingly, ignition delay increases from 0.87 to $2.00 \mathrm{~s}$. Powders having more than 3-micron average particle diameter ( $\mathrm{Al}_{-} 05$ and $\mathrm{Al}_{-}$06) did not ignite with this technique, because laser heating was not enough to reach the ignition temperature.

\section{EFFECTS OF NANOSIZED ALUMINUM POWDERS ON COMBUSTION PROCESSES OF HYBRID SOLID FUELS}

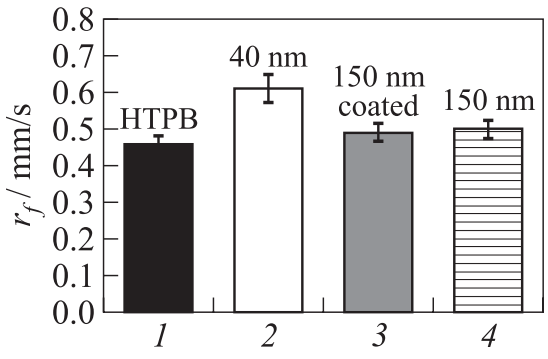

Figure 14 Average regression rates obtained for different fuel formulations: $1-$ pure HTPB; $2-90 \%$ НTPB $+10 \%$ Al_09b; $3-90 \%$ HTPB $+10 \%$ Al_07; and $4-90 \%$ HTPB $+10 \%$ Al_01c. Total mass flux $140 \mathrm{~kg} /\left(\mathrm{m}^{2} \cdot \mathrm{s}\right)$
Tests were performed in the $2 \mathrm{D}$ slab hybrid burner setup at SPLab in order to compare the behavior of different fuel formulations filled with the investigated $\mathrm{Al}$ powders. Three fuels were tested and compared to pure HTPB (used as a baseline). Tested fuels contained 90\% HTPB and 10\% Al in mass fraction. The selected powders were representative of the finest $\left(\mathrm{Al} \_09 \mathrm{~b}\right)$, coated $\left(\mathrm{Al} \_07\right)$, and uncoated $\left(\mathrm{Al}_{-} \mathrm{Oc}\right)$, having the same size allowing investigation of particle size and coating effects on fuel performance.

Tests were performed in pure oxygen at $140 \mathrm{~kg} /\left(\mathrm{m}^{2} \mathrm{~s}\right)$ total mass flux. 
Average regression rate $r_{f}$ was measured in each test and the results are shown in Fig. 14. Reported values were obtained as the standard deviation value over the combustion tests performed for each fuel formulation.

Results in Fig. 14 show that the particle size plays a major role in fuel performance. Finer particles result in the enhanced fuel regression rate: the finer powder (average particle size $40 \mathrm{~nm}$ ) leads to $+32.6 \% r_{f}$ with respect to pure HTPB, while other powders (average particle size $150 \mathrm{~nm}$ ) lead to less significant increases $(+6.5 \%$ for coated powder and $+8.7 \%$ for uncoated). The presence of coating does not seem to affect the regression rate results: the difference between the fuels prepared with coated $\left(\mathrm{Al}_{-} 07\right)$ and uncoated (Al_01c) powder lays within the experimental uncertainty.

\section{EFFECTS OF NANOSIZED ALUMINUM POWDERS ON COMBUSTION PROCESSES OF SOLID ROCKET PROPELLANTS}

The condensed combustion products (CCPs) have been studied extensively, and significant contributions can be found in [26, 27]. The performed investigation of CCP aims at obtaining an estimation of the influence of $\mathrm{nAl}$ powders on combustion processes of solid propellants. Two laboratory formulations consisting of $68 \%$ AP oxidizer, $17 \%$ HTPB binder, and $15 \%$ Al fuel were selected to investigate peculiar effects connected with $\mathrm{nAl}$, emphasizing differences with respect to the usual microsized Al powders. The two AP/HTPB based propellants, including Al_01a and Al_05 powders, were manufactured and tested at SPLab. Further details about the composition and the properties are summarized in Table 5 .

Metal powders in the micrometric range burn according to a distributed mechanism extending much beyond the gas-phase flame thickness and thus not

Table 5 Propellant composition, density, burning rate of the investigated propellants to test the effects of $\mathrm{Al}$ powder size on the condensed combustion products

\begin{tabular}{|c|c|c|c|c|c|}
\hline \multicolumn{6}{|c|}{$\begin{array}{c}\text { AP/HTPB } / \mathrm{Al} \text { propellants } \\
\text { AP grain size: } 150( \pm 10) \mu \mathrm{m}, 80 \%+75( \pm 5) \mu \mathrm{m}, 20 \%\end{array}$} \\
\hline $\begin{array}{c}\text { Propel- } \\
\text { lant }\end{array}$ & $\begin{array}{c}\mathrm{Al} \\
\text { powder }\end{array}$ & $\begin{array}{c}\text { BET } \\
\text { diameter, } \\
\mu \mathrm{m}\end{array}$ & $\begin{array}{c}\text { Propellant } \\
\text { density, } \\
\mathrm{g} / \mathrm{cm}^{3}\end{array}$ & $\begin{array}{c}\text { Binder } \\
\text { composition, \% } \\
\text { HTPB + DOA } \\
+ \text { IPDI }\end{array}$ & Vieille law \\
\hline$P_{-} 05$ & $\overline{\mathrm{Al}}+05$ & 22.16 & 1.517 & $17 \%$ & $r_{b}=(1.320 \pm 0.034) p^{0.392 \pm 0.009}$ \\
\hline$P_{-} 01$ & $\mathrm{Al}_{-} 01 \mathrm{a}$ & 0.15 & 1.672 & $17 \%$ & $r_{b}=(2.420 \pm 0.070) p^{0.375 \pm 0.011}$ \\
\hline
\end{tabular}




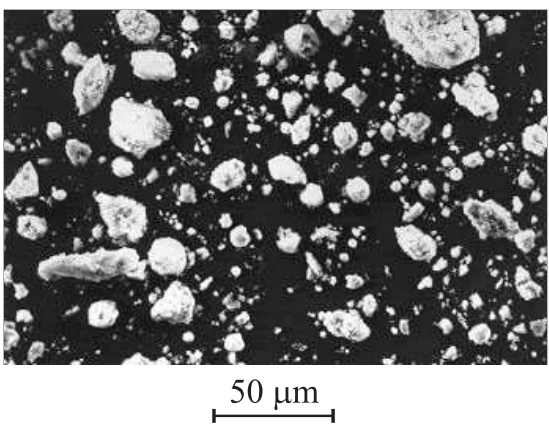

(a)

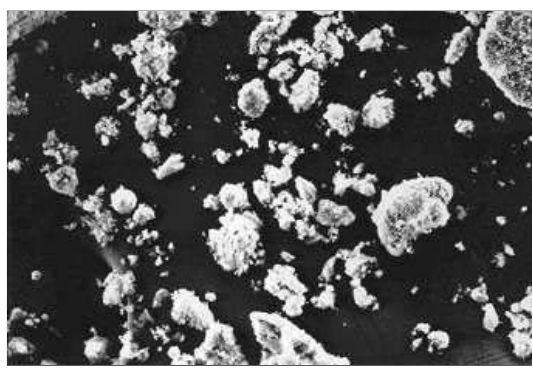

$50 \mu \mathrm{m}$

(b)

Figure 15 The SEM micrographs of propellant P_01 CCPs; magnification $500 \times$; pressure: 1 bar $(a)$ and 30 bar $(b)$

affecting the essentially diffusive combustion process typical of composite propellants. Experimental results in the nanometric range show a remarkable steady burning rate augmentation. When $\mathrm{nAl}$ particles are used, the steady burning rate neatly increases, testifying that the gas-phase flame structure is affected by the combined effects of earlier ignition (see section 4) and fast premixed burning.

The analysis of condensed-phase combustion products shows a greater efficiency of the combustion process when $\mathrm{nAl}$ particles are included in the propellant formulation. Under the limits of the explored operating conditions, the comparison of $\mathrm{P}_{-} 01$ and $\mathrm{P}_{-} 05$ propellants shows that $\mathrm{nAl}$ decreases the mass of unburned metal contained in the agglomerates (-19\% at 30 bar), and increases the $\mathrm{Al}$ oxide content ( $+20 \%$ at 30 bar). In particular, SEM magnifications of combustion residues, collected at 1- and 30-bar chamber pressure, highlight the shape of the agglomerates. For propellant $\mathrm{P}_{-}$05, at a pressure of 1 bar, the estimated average size of residues is $50 \mu \mathrm{m}$, while at 30 bar, the average size is approximately $10 \mu \mathrm{m}$. The trend for $\mathrm{P}_{-} 01$ propellant residues is not significantly affected by a pressure change; the average size is less than $10 \mu \mathrm{m}$ in both cases, as shown in Figs. $15 a$ and $15 b$.

The analysis performed by XPS allows determining the atomic concentration of chemical elements at the surface of the residues. Significant amounts of carbon are correlated to partially oxidized organic material (pyrolysis products); this suggests the interaction between the metal residence time on the carbonaceous layer and the burning of this layer. If the carbonaceous layer burning is slow, the metal detaches from the burning surface and small fractions of the layer remain attached to the metal itself. Carbon comes from pyrolysis processes and is partially oxidized. Aluminum is the total $\mathrm{Al}$, mainly detected as $\mathrm{Al}_{\mathrm{ox}}$, while $\mathrm{Al}_{\text {met }}$ contained inside CCP does not appear in the XPS analysis of the 
residues. Chlorine is probably chlorine from AP decomposition, entrapped in the CCP.

The XRD analysis shows a low content of $\alpha-\mathrm{Al}_{2} \mathrm{O}_{3}$ (Corundum) and the appearance of metastable transition aluminas, such as $\gamma-\mathrm{Al}_{2} \mathrm{O}_{3}$ and $\delta^{*}-\mathrm{Al}_{2} \mathrm{O}_{3}$. The $\mathrm{Al}$ particles oxidation process is very fast, starting at low temperature, going to high temperature until the quenching determined by the implemented collection system. All these formation processes occur in nonequilibrium thermodynamic conditions, and all the formed phases are likely to be frozen by the quenching procedure. This could reasonably explain the presence of both the metastable transition aluminas and the low content of corundum found in all the samples. For increasing pressure, the combustion efficiency increases: total elementary $\mathrm{Al}$ (not combined) decreases because of the increase of the oxide fraction. Not enough data are available to determine the concentration trend of intermediary alumina phases vs. pressure increase.

The importance of the performed CCP analysis is to stress that smaller CCP sizes imply reduced $I_{s}$ losses, and reduced particulate damping effects, especially at low pressures. Cold cohesion, which is typical of $\mathrm{nAl}$, and hot agglomeration, which is typical of $\mathrm{Al}$ powders in general, control the $\mathrm{Al}$ particle actual size before and during the combustion processes, involving several aspects of propulsive systems. In conclusion, density, improved ballistic properties, reduced hot agglomeration phenomena, and improved $I_{s}$ were observed using $\mathrm{nAl}$.

\section{CONCLUDING REMARKS}

A series of $\mathrm{Al}$ nanopowders were examined and compared with the final goal to evaluate their application in solid and hybrid rocket propulsion. The Al powders were characterized using several investigation techniques; results were compared to microsized powders. Aluminum powders having different particle size, different age, different coating were investigated in terms of surface area, morphology, chemical species characteristics (XRD technique) and concentrations (XPS technique). Ignition temperature and ignition delay were measured: the finest powder investigated (0.04-micrometer average particle diameter) displays an ignition temperature decrease of about $50 \%$ when compared to the coarsest powder (about 3-micrometer average particle diameter), confirming that nAl particles manifest a strong reactivity, mainly due to their increased specific surface (see Table 1), notwithstanding the simultaneous decrease of active $\mathrm{Al}\left(\mathrm{Al}_{\text {met }}\right)$ content.

Solid fuels for hybrid rockets were manufactured and tested in order to correlate their regression rate to the properties of the $\mathrm{nAl}$ powder used. Increasing average particle size appears to be detrimental to regression rate results; the presence of a palmitic acid coating shows no effect on fuel performance. 
Two AP/HTPB/Al propellants were also manufactured and burned, using the same composition with different $\mathrm{Al}$ powder size. Combustion tests were performed in the pressure range $1-70$ bar. Steady burning rates significantly increase for the propellant containing $\mathrm{nAl}$, thanks to $\mathrm{nAl}$ strong reactivity, due to an increase of the premixed heat release contribution without much affecting neither the main diffusive heat release contribution nor the CCP average size. The results obtained under operating conditions typical of solid rocket propulsion show larger steady burning rates, with essentially the same pressure sensitivity, when $\mathrm{nAl}$ size decreases. Aggregation and agglomeration phenomena still occur, but their effects may be reduced by using $\mathrm{nAl}$ instead of $\mu \mathrm{Al}$, because of the reduced average size of CCP, thus improving the specific impulse for the mitigation of the two-phase losses.

Further investigation is needed to investigate the effect of $\mathrm{Al}$ particle coating type, aging, and particle cold cohesion on solid propellant or solid fuel ballistic performance. An investigation is already underway to determine the effect of $\mathrm{Al}$ particle size on solid propellant and solid fuel mechanical properties. Visualization techniques will be implemented to better understand the agglomeration and combustion mechanisms of metal powders for both solid propellants and solid fuels.

\section{REFERENCES}

1. Price, E. W. 1984. Combustion of metalized propellants. In: Fundamentals of solid propellants combustion. Eds. K. K. Kuo and M. Summerfield. Progress in aeronautics and astronautics ser. AIAA. 90:478-513.

2. Babuk, V.A., V.P. Belov, V.V. Khodosov, and G. G. Shelukhin. 1985. Investigation of the agglomeration of aluminum particles during the combustion of metallized composite condensed systems. Combust. Explosion Shock Waves 21(3):28792.

3. Dreizin, E. L. 1996. Experimental study of stages in aluminum combustion in air. Combust. Flame 105(4):541-56.

4. Ivanov, G. V., and F. Tepper. 1997. Activated aluminum as a stored energy source for propellants. In: Challenges in propellants and combustion 100 years after Nobel. Ed. K. K. Kuo. New York: Begell House. 636.

5. Mench, M. M., C.L. Yeh, and K. K. Kuo. 1998. Propellant burning rate enhancement and thermal behaviour of ultra-fine aluminum powders (Alex). In: Energetic Materials: Production, Processing and Characterization. 29th Annual Conference (International) of ICT Proceedings. Karlsruhe, Germany. 30-1-15.

6. Kwok, Q., R. C. Fouchard, A.M. Turcotte, et al. 2002. Characterization of aluminum nanopowder compositions. Propellants Explosives Pyrotechnics 27(4):22940. 
7. Dokhan, A., E.W. Price, J. M. Seitzman, and R. K. Sigman. 2003. The ignition of ultra-fine aluminum in ammonium perchlorate solid propellant flames. AIAA Paper No. 2003-4810.

8. Babuk, V. A., I. Dolotkazin, A. Gamsov, A. Glebov, L. T. DeLuca, and L. Galfetti. 2009. Nanoaluminum as a solid propellant fuel. J. Propul. Power 25(2):482-89.

9. Bazyn, T., H. Krier, and N. Glumac. 2007. Evidence for the transition from the diffusion-limit in aluminum particle combustion. Proc. Combust. Inst. 31:2021-28.

10. Lynch, P., N. Glumac, and H. Krier. 2008. Combustion of aluminum particles in the transition regime between the diffusion and kinetic limits. AIAA Paper No. 20085256 .

11. Lynch, P., H. Krier, and N. Glumac. 2009. A correlation for burn time of aluminum particles in the transition regime. Proc. Combust. Inst. 32:1887-93.

12. Meda, L., G. L. Marra, R. Braglia, L. Abis, R. Gallo, F. Severini, L. Galfetti, and L.T. DeLuca. A wide characterization of aluminum powders for propellants. 9th Workshop (International) on Combustion and Propulsion Proceedings. Novel energetic material and applications. Ed. G.S.S. Grafiche. Bergamo, Italy. Paper No. 17.

13. Gromov, A. A., U. Forter-Barth, E. M. Popenko, and U. Teipel. 2006. Effect of nanoaluminum (Alex) additions on the rheology of energetic mixtures. Workshop (International) HEMs-2006 Proceedings. Belokurikha, Russia.

14. Risha, G. A., A. Ulas, E. Boyer, S. Kumar, and K. K. Kuo. 2001. Combustion of HTPB-based solid fuels containing nano-sized energetic powder in a hybrid rocket motor. AIAA Paper No. 2001-3535.

15. Evans, B., N. A. Favorito, E. Boyer, G. A. Risha, R. B. Wehrman, and K. K. Kuo. 2004. Characterization of nano-sized energetic particle enhancement of solid-fuels burning rates in a X-ray transparent hybrid rocket engine. AIAA Paper No. 20043821.

16. Evans, B. J., N. A. Favorito, and K. K. Kuo. 2006. Oxidizer-type and aluminumparticle addition effects on solid-fuel burning behavior. AIAA Paper No. 2006-4676.

17. Bazyn, T., H. Krier, and N. Glumac. 2006. Combustion of nanoaluminum at elevated pressure and temperature behind reflected shock waves. Combust. Flame 145(4):703-13.

18. Brunauer, S., P.H. Emmett, and E. Teller. 1938. Adsorption of gases in multimolecular layers. J. Amer. Chem. Soc. 60:309-19.

19. Rietveld, H. M., A. C. Larson, and R. B. Von Dreele. 1987. General structure analysis system (GSAS). Los Alamos National Laboratory. Report No. LA-UR-68-748. Los Alamos, NM, USA.

20. Cheary, R.W., and A.A. Coelho. 1992. A fundamental parameters approach of X-ray line-profile fitting. J. Appl. Cryst. 25:109-21.

21. DeLuca, L. T., L. Galfetti, F. Severini, L. Meda, G. Marra, A. B. Vorozhtsov, V.S. Sedoi, and V.A. Babuk. 2005. Burning of nano-aluminized composite rocket propellants. Combust. Explosion Shock Waves 41(6):680-92.

22. DeLuca, L. T. 2007. Burning of aluminized solid rocket propellants: From micrometric to nanometric fuel size. Seminar (International) on Propellants, Explosives and Pyrotechnics. Kumning, China. 
23. Merotto, L., M. Boiocchi, L. Galfetti, G. Colombo, F. Carea, and L. T. DeLuca. 2009. Experimental investigation of metallized hybrid rocket fuels. 3rd European Conference for Aero-Space Sciences. Versailles, Paris.

24. Eisenreich, N., H. Fietzek, M. Del Mar Juez-Lorenzo, V. Kolarik, A. Koleczko, and V. Weiser. 2004. On the mechanism of low temperature oxidation for aluminum particles down to the nano-scale. Propellants Explosives Pyrotechnics 29(3):13745.

25. Cliff, M., F. Tepper, and V. Lisetsky. 2001. Ageing characteristics of Alex nanosized aluminum. AIAA Paper No. 2001-3287.

26. Glotov, O. G. 2000. The condensed combustion products of aluminized solid propellants. Evolution of particles with distance from the burning. Combust. Explosion Shock Waves 36(4):476-87.

27. Babuk, V. A., V. A. Vassiliev, and V. V. Sviridov. 2001. Propellant formulation factors and metal agglomeration in combustion of aluminized solid rocket propellant. Combust. Sci. Technol. 163(1):261-89. 